\title{
BIOLOGY OF THE PREDAEOUS MITE Cheyletus eruditus (SCHRANK) (ACARI: CHEYLETIDAE) WHEN FED ON THE ASTIGMATID MITE Acarus siro(OUDEMANS) AT DIFFERENT TEMPERATURES \\ KarimaM.Metwalley ${ }^{1}$;M.E.El-Naggar ${ }^{2}$;F.M.Abou Senna ${ }^{3}$; \\ Wedad A. Atwa ${ }^{1}$ and Zeinab, M. Mahgoub ${ }^{2}$. \\ 1-Department of Zoology, Faculty of Science for Girls, Al- \\ Azhar University. \\ 2-Plant Protection Research Institute, A.R.C. Giza \\ 3- Department of Zoology, Faculty of Science, Al-Azhar \\ University.
}

\begin{abstract}
The mite species Cheyletus eruditus was reared on eggs and immatures of the acarid mite, Acarus siro (Oudemans) at 20 and $30^{\circ} \mathrm{C}$. All biological aspects of the predator were significantly affected by the temperature. The incubation period, life cycle and longevity of males and females were significantly increased when the cheyletid mite fed on A. siro eggs at $20^{\circ} \mathrm{C}$. in comparison with $30^{\circ} \mathrm{C}$. Incubation period of $C$. eruditus significantly differed between the male and female and further more between the different temperature degrees. The longest incubation period recorded when the males fed on the immature of $A$.siro 8.3 days at $20^{\circ} \mathrm{C}$ and the shortest period 4.4 days when the male fed on eggs of $A$. siro at $30^{\circ} \mathrm{C}$. The female life cycle durated 30.7 and 19.1 days on eggs of $A$.siro at 20 and $30^{\circ} \mathrm{C}$, respectively, changed to 24.8 and 14.4 days when the males fed on the same prey, respectively, On the other hand, when the immatures of $A$. siro were used, $C$. eruditus life cycle lasted 32.6, 24.7; 19.9 and 15.1 days for the females and males, respectively. The adult female longevity of $C$. eruditus differed and reached to the highest level when fed on eggs of A. siro at $20^{\circ} \mathrm{C}$ recorded 42.9 days and showed the shortest period when the males fed on immature stages of A.siro (14.0 days). The generation period of $C$. eruditus female durated 36.1 and 21.2 days when fed on eggs of $A$.siro at 20 and $30{ }^{\circ} \mathrm{C}$, changed to recorded 36.6 and 22.5 days when the mites fed on immature stages of A.siro. Fecundity was significantly higher when the female fed on eggs of $A$. siro record 49.92 eggs at $30{ }^{\circ} \mathrm{C}$ and decreased to recorded the lowest number of deposited eggs at 20 ${ }^{\circ} \mathrm{C}$ when the females fed on immature stages of A.siro (33.0 eggs). During the longevity and life span of $C$. eruditus females, the mites consumed 282.7 and 344.8 eggs of A.siro at $20 \mathrm{C}$ respectvely, changed to record 130.7 and 147 eggs of $\mathrm{A}$. siro in case of male individuals at the same temperature. While at the female consumed 236.0 and 268.0 immatures of $A$. siro and male consumed 150 and 158 immatures of A.siro at the same temperature. When eggs of $A$. siro introduced as prey for $\mathrm{C}$. eruditus at $30{ }^{\circ} \mathrm{C}$, the female of the predator consumed 340.5 and 436 and males consumed 220 and 247 eggs during longevity and life span, changed to record 315.0 and 387 immatures of $A$.siro in case of adult female of the predator and 150 and 163.6 immatures in case of male individuals in the same temprature.
\end{abstract}

\section{INTRODUCTION}

There is ample evidence that predators and parasitoids can play a significant role in the decline of moth populations in storages. Graham (1970), for example, described the buildup and decline of Cadra cautella (Walker) 
(Lepidoptera: Pyralidae) (infesting bagged maize in Kenya, and concluded that predation by the mite Blattisocius tarsalis Berlese (Acarina: Ascidae) was the major cause of decline. Several mite predators have been documented to be associated with or even considered to be biological control agents against certain species of these pests. But much of the research has been restricted either to the laboratory studies, the biology of $C$. malaccensis was studied in the laboratory, using eggs of Corcyra cephalonica as prey, Nangia et al., (1994). The authors noticed that the predator egg, larval, protonymph and deutonymph stages lasted $6.0,3.0,4.0$ and 4.0 days, respectively. The average fecundity was 58.6 eggs/female. Cannibalism was common in the adult stage. Adult females exhibited partial parental care, guarding eggs for 2.0 days or until the larva emerged. Also a study was carried out on the life history of C. malaccensis when fed on Lepidoglyphus destructor by Zhang et al., (1997). The whole life history required 48-50 days, including 5 stages (eggs, larvae, protonymphal and deutonymphal stage, and adults). Each mite consumed approximately 10-12 prey items / day and a total of 500 prey items during its life time. The predatory capacity decreased (with an unchanged number of prey) when the density of $C$. malaccensis increased. Yassin et al., (2008) studied the feeding of the cheyletid mite, Cheletomorpha lepidopterorum (Schaw) on different astigmatid mites and mentioned that $T$. putrescentiae was the most favorable preys than Lepidoglyphus destructor, Rhizoglyphus echinopus and Caloglyphus betae and this might be due to $T$. putrescentiae contained the highest contents of total sugar and high relative concentration of glucose. Future studies should further contribute to improvement of rearing of this predator. Our data provide fundamental information for understanding the effect of different stages of stored product pest (Acarus siro) on development of the cheyletid mite, C. eruditus Future studies should further contributed to improvement of rearing of this predator at different conditions on different prey and this will increase its ability as a biological control agent. Mohamed et al., (2012) reared C. eruditus on different sources of food (eggs and immatures of Rhizoglyphus robini and eggs of Plodia interpunctella (Hubner) and eggs of Callosobruchus maculatus (Fabricus) at different temperature and recorded that the type of prey and temperature affected significantly on $C$. eruditus males and females. The present work aim to study the effect of different prey and temperature on biological aspects, fecundity of the predatory mite , Cheyletus eruditus (shrank)

\section{MATERIALS AND METHODS}

Females and Males of the cheyletid mite, Cheyletus eruditus were isolated from standing cultures and transferred into small plastic diameter, 4 $\mathrm{cm}$ in depth). The bottom of the cell was covered with a mixture of plaster of Paris: charcoal (9: 1) and tightly covered by a glass slide as mentioned by Kandil (1982) and Salem et al., (2005).The upper par of vials was surrounded by Vaseline to avoid escaping of mites. Newly hatched predatory larvae (protonymphs and deutonymphs) were confined singly in other cells and supplied with a known number of $A$.siro (eggs and immature stages) as prey 
mites till reaching maturity. Drops of water were added daily to maintain suitable moisture. Emerging mite females were copulated with males and supplied with known number of eggs. All biological aspects of the predator were conducted at 20 and $30+2{ }^{\circ} \mathrm{C}$ and $70+5 \%$ R.H. All presented data were subjected to one-way analysis of variance (ANOVA) and means were separated by Duncan's multiple range test (Duncan 1955).

Biological studies: In this study, the trials were conducted in the laboratory conditions (20 and $30{ }^{\circ} \mathrm{C}$ ) and relative humidity $75 \%$ to study the different biological aspects of the predaeous cheyletid mite, Cheyletus eruditus when fed on the astigmatid mite Acarus siro (eggs and immature stages).

Habitat and feeding: Cheyletus is mainly free-living predator that feed on various microarthropods, particularly herbivorous, fungivorous and saprophagous acaroid mites (Zdarkova, 1979). Cheyletids penetrate insects and mites with their chelicerae and immediately inject saliva that paralyzes the prey (Yoshikawa, 1985).

Mating: Virgin females of Cheyletus gave rise to male progeny (100\%), while fertilized females produced both sexes, Palyvos et al., (2008).

Moulting: The presence of an exuvium was used criterion for successful moulting between each mite stage and the following one. In this stage the mite stops feeding and movement, and the quiescent individual practiced several movements to loosen itself from the old glassy witish exuviae these continuous movements resulted in an n-shape rupture surrounding anterior and lateral sides of the prodosoma.

\section{RESULTS AND DISCUSSION}

Incubation period: Incubation period of the predatory mite $C$. eruditus significantly differed through the research and has been varied between the male and female and further more between the different temperature degrees. The tabulated data in Tables (1\&2) showed that the incubation period of $C$. eruditus significantly differed when the individuals (males and females) fed on the two types of prey, as it recorded $8.1,8.2 ; 4.5$ and 4.4 days when female and male fed on eggs of A.siro at 20 and $30{ }^{\circ} \mathrm{C}$, respectively, Table (1), while these periods recorded $8.2,8.3 ; 4.8$ and 4.9 days when the same mites fed on the immature stages of the astigmatid mite, A. siro at the same conditions, Table (2).

Life cycle: The prey and temperature suitability clearly affects the life cycle of $C$. eruditus. From the obtained data, Tables (1 and 2) it was showed that the female life cycle durated 30.7 and 19.1 days when fed on eggs of $A$.siro at 20 and $30{ }^{\circ} \mathrm{C}$, respectively, changed to 24.8 and 14.4 days when the male individuals fed on the same prey at the conditions, respectively, Table (1). on the other hand, when the immature stages of $A$. siro were used as food type, 
Table (1): Duration of the different stages of predatory mite Cheyletus eruditus when fed on eggs of Acarus siro at different temperatures

\begin{tabular}{|c|c|c|c|c|c|c|}
\hline \multirow{2}{*}{\multicolumn{2}{|c|}{$\begin{array}{l}\text { Developmental } \\
\text { stage }\end{array}$}} & \multicolumn{2}{|c|}{$20^{\circ} \mathrm{C}$} & \multicolumn{2}{|c|}{$30^{\circ} \mathrm{C}$} & \multirow{2}{*}{$\begin{array}{l}\text { L.S.D. at } \\
0.05\end{array}$} \\
\hline & & Female & Male & Female & Male & \\
\hline \multicolumn{2}{|c|}{ Incubation period } & $8.1+0.55$ & $8.2 \pm 0.64$ & $4.5+0.42$ & $4.4+0.37$ & 0.572 \\
\hline \multirow{2}{*}{ Larva } & $\mathrm{A}$ & $6+0.47$ & $6.8 \pm 0.27$ & $3.8+0.21$ & $3.9 \pm 0.19$ & 0.355 \\
\hline & Q & $1 . \overline{5}+0.11$ & $1.4+0.11$ & $1.3+0.12$ & $1.4 \pm 0.13$ & 0.122 \\
\hline \multirow{2}{*}{ Deutonymph } & $\mathrm{A}$ & $6.4 \pm .0 .32$ & $6.9+0.3$ & $3.2+0.3$ & $3.5+0.21$ & 0.367 \\
\hline & $Q$ & $1.4 \pm 0.13$ & $1.5 \pm 0.14$ & $1.1 \pm 0.1$ & $1.3 \pm 0.11$ & 0.138 \\
\hline \multirow{2}{*}{ Deutonymph } & $\mathrm{A}$ & $5.7 \pm 0.32$ & - & $3.8 \pm 0.24$ & - & 0.320 \\
\hline & Q & $1.6+0.12$ & - & $1.4 \pm 0.09$ & - & 0.111 \\
\hline \multicolumn{2}{|l|}{ Life cycle } & $30 . \overline{7} \pm 1.6$ & $24.8 \pm 1.0$ & $19.1 \pm 0.84$ & $14.4 \pm 0.75$ & 1.68 \\
\hline \multicolumn{2}{|c|}{ Generation period } & $36.1+1.5$ & - & $21.2 \pm 1.5$ & - & 2.15 \\
\hline \multicolumn{2}{|c|}{ Longevity } & $42.9 \pm 2.2$ & $28.0 \pm 1.6$ & $25.2 \pm 1.4$ & $15.2 \pm 0.97$ & 3.14 \\
\hline \multicolumn{2}{|l|}{ Life span } & $73.8+3.2$ & $52.8+2.9$ & $44.6 \pm 3.1$ & $29.3+1.3$ & 5.24 \\
\hline \multicolumn{2}{|l|}{ Fecundity } & $40.5 \pm 2.5$ & - & $49.92 \pm 3.4$ & - & 3.36 \\
\hline
\end{tabular}

Table (2): Duration of the different stages of predatory mite Cheyletus eruditus when fed on immature stages of Acarus siro at different temperatures

\begin{tabular}{|c|c|c|c|c|c|}
\hline \multirow{2}{*}{$\begin{array}{l}\text { Developmental } \\
\text { stage }\end{array}$} & \multicolumn{2}{|c|}{$20^{\circ} \mathrm{C}$} & \multicolumn{2}{|c|}{$30^{\circ} \mathrm{C}$} & \multirow{2}{*}{ L.S.D. at 0.05} \\
\hline & Female & Male & Female & Male & \\
\hline Incubation period & $8.2+0.65$ & $8.3+0.47$ & $4.8+0.27$ & $4.9+0.33$ & 0.584 \\
\hline \multirow{2}{*}{ Larva } & $6.9 \pm 0.44$ & $6.9+0.34$ & $4.0 \pm 0.24$ & $0 . \overline{365}$ & 0.365 \\
\hline & $1.5+0.11$ & $1.6+0.14$ & $1.4+0.10$ & 0.123 & 0.123 \\
\hline \multirow{2}{*}{ Deutonymph } & $6.9+0.33$ & $6.4+0.41$ & $3.3+0.24$ & 0.387 & 0.387 \\
\hline & $1.3 \pm 0.11$ & $1.5+0.12$ & $1.2 \pm 0.16$ & 0.142 & 0.142 \\
\hline \multirow{2}{*}{ Deutonymph } & $6.5+0.41$ & - & $4.0+0.38$ & 0.321 & 0.321 \\
\hline & $1.3+0.09$ & - & $1.2+0.11$ & 0.102 & 0.102 \\
\hline Life cycle & $32 . \overline{6}+16$ & $24.7+1.1$ & $19 . \overline{9+0.89}$ & $15.1+0.67$ & 1.81 \\
\hline Generation period & $36.6+1.2$ & - & $22.5+0.97$ & - & 2.32 \\
\hline Longevity & $40.2+1.6$ & $22.0+1.0$ & $22 . \overline{1+1.4}$ & $14.0+0.74$ & 3.06 \\
\hline Life span & $72.2+3.5$ & $46.7+2.7$ & $42.0+2.4$ & $29.1+1.4$ & 5.20 \\
\hline Fecundity & $33.0+2.2$ & - & $37.5+2.8$ & - & 3.66 \\
\hline
\end{tabular}

The predatory mite $C$. eruditus life cycle lasted $32.6,24.7 ; 19.9$ and 15.1 days for the females and males, respectively, Table (2)

Longevity: Concerning the adult female longevity of $C$. eruditus, Tables (1 and 2), it was observed that this period differed on the different tested food, reached to the highest level when the female individuals fed on eggs of $A$. siro at $20{ }^{\circ} \mathrm{C}(42.9$ days) and showed the lowest period when the males fed on immature stages of A. siro (14.0 days) at $30 \mathrm{C}^{0}$. 
Generation period: As shown in Tables (1 and 2), the generation period of C. eruditus female durated 36.1 and 21.2 days when the individuals fed on eggs of $A$. siro at 20 and $30{ }^{\circ} \mathrm{C}$, Table (1), changed to recorded 36.6 and 22.5 days when the mites fed on immature stages of $A$. siro, Table (2).

Life span: Accordingly, the life span of $C$. eruditus, also highly affected by the types of food. The female life span of this mite was 73.8, 52.8; 44.6 and 29.3 days when the females and males of the predatory mite, $C$. eruditus fed on eggs of $A$. siro at 20 and $30^{\circ} \mathrm{C}$, respectively, Table (1). On the other hand, when the immature stages of the astigmatid mite, A.siro were used as rearing source, the life span of $C$. eruditus took $72.2,46.7 ; 42.0$ and 29.1 days, respectively at the same used conditions, Table (2).

Fecundity: Mating is essential for egg deposition of C. eruditus Eggs production in $C$. eruditus was influenced by the type of used food, Tables (1and 2). Fecundity was significantly higher when the adult female fed on eggs of $A$. siro recorded 49.92 eggs at $30{ }^{\circ} \mathrm{C}$ and decreased to recorded the lowest number of deposited eggs at $20^{\circ} \mathrm{C}$ when the females fed on immature stages of $A$. siro (33.0 eggs), Table (2)

Predation capacity of $C$. eruditus on eggs and immatures of $A$. siro at $20{ }^{\circ} \mathrm{C}$. The predatory mite $C$. eruditus females preyed upon $A$. siro eggs with an average of $11.5,20.2,30.4,35.5,196.6,50.2,282.7$ and 344.8 eggs of the astigmatid mite $A$. siro during larva, protonymph, deutonymph, Preoviposition period, oviposition period, postoviposition period, longevity and life span, respectively, but the same individuals consumed 130.7 and 147.0 eggs in case of male during longevity and life span period at $20^{\circ} \mathrm{C}$, Table (3). On the other hand, the female individuals of the predator preyed on 7.0, 10.2, $15.1,18.2,177.2,40.3,236.0$ and 268.0 immature stages of A.siro at $20 \mathrm{C}$, for the same previously mentioned stages of $C$. eruditus female, but in case of longevity and life span of male individuals, the mites consumes an average of 150.0 and 158.0 immatures of A.siro, respectively, Table (3). $30^{\circ} \mathrm{C}$

Predation capacity of $C$. eruditus on eggs and immatures of $A$. siro at

As shown in Table (4) the predatory mite, C. eruditus males and females (different stages) fed successfully on the astigmatid mite, $A$. siro at $30{ }^{\circ} \mathrm{C}$ with the same trend in case of $20{ }^{\circ} \mathrm{C}$, but differed in the number of consumed preys of $A$. siro eggs and immature. The obtain data indicated that during the oviposition period of $C$. eruditus the mites consumed 250.2 eggs and 230.2 immatures of $A$.siro .On the other hand, the male individuals of $C$. erudits preyed on 150.3 and 163.0 immature stages and 220, 247 eggs of $A$. siro during its longevity and life span respectively Table (4). 
Table (3): Efficiency of $C$. eruditus as consumed different preys at $20^{\circ} \mathrm{C}$ and $70 \%$ R. $\mathrm{H}$.

\begin{tabular}{|l|c|c|c|}
\hline \multirow{4}{*}{ Type of prey } & $\begin{array}{c}\text { Developmental } \\
\text { stages of C.eruditus }\end{array}$ & \multicolumn{2}{|c|}{$\begin{array}{c}\text { Mean numbers } \mathbf{c} \text { S. E. of prey } \\
\text { consumed by one cheyletid mite }\end{array}$} \\
\cline { 2 - 4 } & Lemale & Male \\
\hline \multirow{4}{*}{ Eggs of $A$. siro } & $11.5 \pm 0.45$ & $3.2 \pm 0.24$ \\
\cline { 2 - 4 } & Protonymph & $20.2 \pm 1.0$ & $13.1 \pm 0.5$ \\
\cline { 2 - 4 } & Deutonymph & $30.4 \pm 1.6$ & - \\
\cline { 2 - 4 } & Preoviposition & $35.5 \pm 1.8$ & - \\
\cline { 2 - 4 } & Oviposion & $196.6 \pm 6.4$ & - \\
\cline { 2 - 4 } & Postoviposition & $50.2 \pm 2.5$ & - \\
\cline { 2 - 4 } & Longevity & $282.7 \pm 6.8$ & $130.7 \pm 5.5$ \\
\cline { 2 - 4 } Immatures of & Life span & $344.8 \pm 7.4$ & $147.0 \pm 5.8$ \\
\hline A.siro & Larva & $7.0 \pm 0.35$ & $3.0 \pm 0.16$ \\
\cline { 2 - 4 } & Protonymph & $10.2 \pm 0.65$ & $5.0 \pm 0.34$ \\
\cline { 2 - 4 } & Deutonymph & $15.1 \pm 0.87$ & - \\
\cline { 2 - 4 } & Preoviposition & $18.2 \pm+1.2$ & - \\
\cline { 2 - 4 } & Oviposion & $177.2 \pm 5.6$ & - \\
\cline { 2 - 4 } & Postoviposition & $40.3 \pm 2.4$ & $150.0 \pm 5.4$ \\
\cline { 2 - 4 } & Longevity & $236.0 \pm 5.0$ & $158.0 \pm 5.2$ \\
\cline { 2 - 4 } & Life span & $268.0 \pm 5.9$ & \\
\hline
\end{tabular}

Table (4): Efficiency of $C$. eruditus as consumed different preys at $30^{\circ} \mathrm{C}$ and $70 \%$ R. $\mathrm{H}$.

\begin{tabular}{|l|c|c|c|}
\hline \multirow{3}{*}{ Type of prey } & $\begin{array}{c}\text { Developmental } \\
\text { stages of C.eruditus }\end{array}$ & \multicolumn{2}{|c|}{$\begin{array}{c}\text { Mean numbers } \mathbf{c} \text { S. E. of prey } \\
\text { consumed by one cheyletid mite }\end{array}$} \\
\cline { 2 - 4 } & & Female & Male \\
\hline \multirow{4}{*}{ Eggs of A. siro } & Larva & $20.2 \pm 1.2$ & $12.0 \pm 0.34$ \\
\cline { 2 - 4 } & Protonymph & $30.1 \pm 1.6$ & $15.0 \pm 0.56$ \\
\cline { 2 - 4 } & Deutonymph & $45.2 \pm 2.5$ & - \\
\cline { 2 - 4 } & Preoviposition & $50.0 \pm 2.7$ & - \\
\cline { 2 - 4 } & Oviposion & $250.2 \pm 5.8$ & - \\
\cline { 2 - 4 } & Postoviposition & $40.3 \pm 2.7$ & - \\
\cline { 2 - 4 } & Longevity & $340.5 \pm 6.8$ & $220.0 \pm 4.2$ \\
\cline { 2 - 4 } Immatures of & Life span & $436.0 \pm 7.8$ & $247.0 \pm 5.8$ \\
\hline A.siro & Larva & $12.0 \pm 0.45$ & $6.2 \pm 0.6$ \\
\cline { 2 - 4 } & Protonymph & $16.0 \pm 0.87$ & $7.1 \pm 0.74$ \\
\cline { 2 - 4 } & Deutonymph & $25.2 \pm 2.6$ & - \\
\cline { 2 - 4 } & Preoviposition & $50.3 \pm+3.5$ & - \\
\cline { 2 - 4 } & Oviposion & $230.2 \pm 6.0$ & - \\
\cline { 2 - 4 } & Postoviposition & $35.3 \pm 2.7$ & $150.3 \pm 5.0$ \\
\cline { 2 - 4 } & Longevity & $315.0 \pm 5.9$ & $163.6 \pm 4.5$ \\
\cline { 2 - 4 } & Life span & $387.0 \pm 6.1$ & \\
\hline
\end{tabular}


Several researchers have studied the biological aspects of the genus Cheyletus and different results were obtained, e.g., regarding developmental stages duration, fecundity, reproduction mode, and prey consumption (Zaher and Soliman 1971; Yousef et al., 1992; Saleh et al. 1986; Nangia et al., 1994; Pekar and Hubert 2008). Those differences may be attributed to the occurrence of various biotypes in different regions of the world (Palyvos and Emmanouel 2004). Other sources of variation would be the ambient temperature (s) or the prey types. The effect of temperature on the development of immature stages of the predator $C$. eruditus Oudemans, produced by either fertilized or virgin females, was studied at 17.5, 20, 25, 30, 32.5 , and $35{ }^{\circ} \mathrm{C}, 80 \pm 5 \%$ relative humidity, in complete darkness, while fed on Tyrophagus putrescentiae, Nickolas et al., (2009). Based on total produced developmental time, males developed more quickly than females, at all temperatures. Also, El-Shannat in Egypt_(2009) studied the biological aspects of the predatory mite, when reared on the grain mite, Acarus siro at 25 and $30^{\circ} \mathrm{C}$ and $90 \%$ R.H. and noticed that the duration of female longevity reached 48.0 and 38.0 days respectively. The number of recorded deposited eggs was 173.0 and 210.0 eggs, respectively at the same temperature. Similar results were obtained by Zaher and Soliman (1971) when reared $C$. malaccensis in the laboratory on Caloglyphus sp.. They noticed that the egg stage averaged 6.6 days at $19.5{ }^{\circ} \mathrm{C}$ and the larval, protonymphal and deutonymphal stages together averaged 19.4 days for females and 16.5 for males at $22{ }^{\circ} \mathrm{C}$. Similar results were also obtained by Rakha et al., (1991) noticed that eggs of Lasioderma serricorne $\mathrm{L}$. seem to be a very adequate prey for this predaceous mite, C. malaccensis. During larval, protonymphal and adult stages, the male consumed 2.0, 4.2 and 2.6 eggs, while the female consumed 2.3, 3.6 and 106.4 eggs, respectively. The efficacy of the cheyletid mite Acaropsis sollers (Rohd.) as a biological control agent on eggs of the southern cowpea beetle, Callosobruchus maculatus (F.) and the cowpea beetle, Callosobruchus chinensis (L.) was studied under laboratory conditions.

\section{REFERENCES}

Duncan, D. B.1955.Multiple range and multiple F.test. Biometrics,11: 1-42.

El-Shannat, H. A. M. 2009. Ecological and biological studies on some important pests of stored grain and seeds. M.Sc. Thesis, Fac. Agric., Kafr El-Sheikh Univ., 178 pp.

Graham, W. M. 1970. Warehouse ecology studies of bagged maize in Kenya-II. Ecological observations of an infestation of Ephestia (Cadra) cautella (Walker) (Lepidoptera, Phycitidae). Journal of Stored Products Research, 6: 157-167.

Mohamed, Shaemaa, A.; A.A. Ebrahim; M.E. El-Naggar; Y.A.Dahroug and E.M. A. Yassin 2012. The biological aspects of the predatory mite, Cheyletus eruditus (Schrank) (Acari: Cheyletidae) reared on three prey species at various constant temperatures. Minufia J. Agric. Res., Vol. 37, No. 6 (1): 1451-1460. 
Nangia, N; G. P. ChannaBasavanna and P. S. Jagadish 1994. The biology of Cheyletus malaccensis (Acari: Prostigmata) a predator of primary acariforms in storage. Current Research University of Agricultural Sciences Bangalore. 24 (1): 13-15

Nickolas, E. P.; G.E. Nickolas and J. S. Costas 2009. Mites associated with stored products in Greece. Experimental \& Applied Acarology, 44 (3): 213-214.

Palyvos, N.E. and N.G. Emmanouel 2004. Seasonal abundance and vertical distribution of mites in flat storage containing wheat. Phytoparasitica, $34(1): 25-36$.

Palyvos, N.E. N.G. Emmanouel and C. J. Saitanis 2008. Mites associated with stored products in Greece. Exp. \& Appl. Acarol.; 44 (3): 213-226.

Pekar, S. and J. Hubert 2008. Assessing biological control of Acarus siro by Cheyletus malaccensis under laboratory conditions: Effect of temperatures and prey density.J. of Stored Prod.Res.44 (4):335-340.

Rakha, M. A; M. E. E. EL-Naggar and I. I. El-Sebbay 1991. Biological studies on the predacious mite Cheyletus malaccensis (Oudemans) (Acari: Cheyletidae) when fed on eggs of Lasioderma serricorne L. Egyptian Society for biological control of pests.77-83.

Saleh, S.; M. S. El-Helaly and F. H. El-Gayar 1986. Life history of the predatory mite Cheyletus malaccensis (Oudemans).Acarologia, 27(1): 37-40.

Salem, S. E.; E. T. E. Darwish, A. M. Zaki and M. A. M. Abou-Tayesh 2005. Efficacy of Acaropsis sollers (Actinedida, Cheyletidae) in the biological control of two cowpea beetle species. J. Pest Cont. \& Environ. Sci., 13 (1): 51-60.

Yassin, E. M. A.; G. M. Sallam and S. A. Ibrahim 2008. Studies on the feeding, reproduction and development of Cheletomorpha lepidopterorum (Schaw) (Prostigmata: Cheyletidae) on various food sources. IOBC/WPRS Bulletin, Vol. 40: 33-52.

Yoshikawa, M. 1985. Ecology and control of mites in Japanese. J. Environ. Control Technol., 3: 4-11.

Yousef, A. A.; M.A. Zaher and M. M. Kandil 1982. Effect of prey and temperature on the development and biology of Cheyletus malaccensis Oudemans (Acari: Cheyletidae). Zeitschrift fur Anagewandate-Entomol., 93 (1): 39-42.

Zaher. A. and Z. R. Soliman 1971. Life-history of the predatory mite Cheyletus malaccensis Oudemans (Acarina: Cheyletidae). Bulletin-dela Societe Entomologique d' Egypte. 1971; 55: 49-53.

Zaki, A. M.; E. T. E. Darwish; A. A. Osman and H. M. A. El-Nenaey 2002. Efficiency of three mite species as biological control agents on eggs of potato tuber moth, Phthorimaea operculella (Gelechiidae, Lepidoptera).Abstr. $7^{\text {th }}$ European Cong. of Entomol., Greece: 212.

Zdarkova E. 1979. Cheyletid fauna associated with stored products in Czechoslovakia. J Stored Prod Res 15:11-16

Zhang, Y. X.; L. J. Zheng and H. A. Pin 1997. Studies on the relationship between Cheyletus malaccensis Oudemans (Acarina: Cheyletidae) and Lepidoglyphus destructor. Journal of Fujian Academy of Agricultural Sciences, 12(1): 44-47 
بيولوجيـة الاكساروس المفترس Cheyletus eruditus (Schrank) عند تغذيته على الاكاروس عديم الثغ الثز

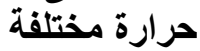
كريمة محمد متولي" , محمود السيد النجار2 , فكرى محمد ابو سنة"3, وداد احمد عطوة'و

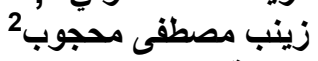

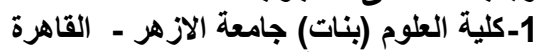

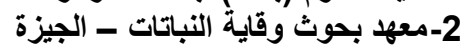

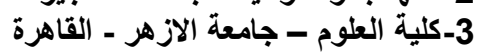

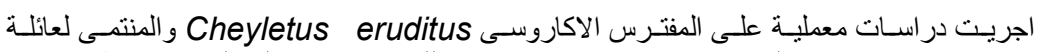
من تحت رتبة الثغر الامامى Cheyletidae

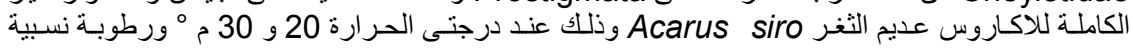

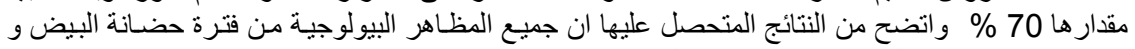

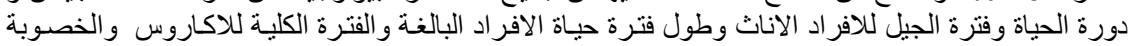

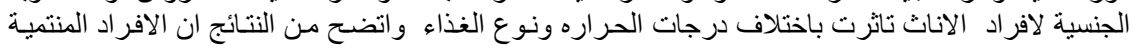

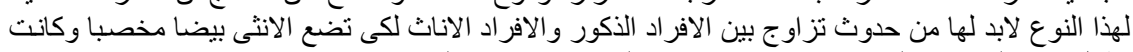

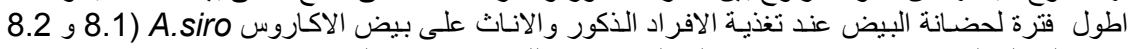

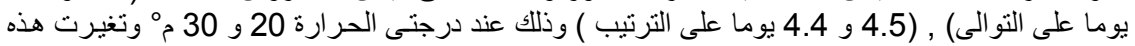

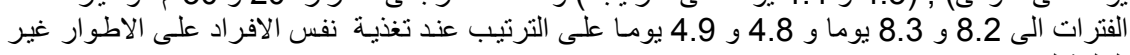

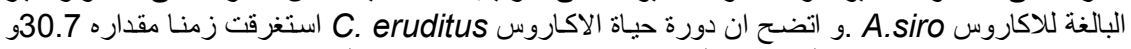

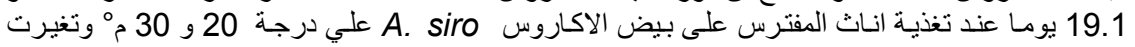

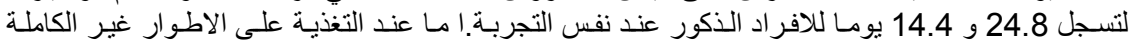

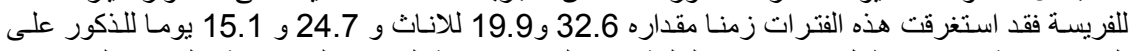

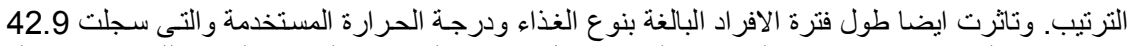

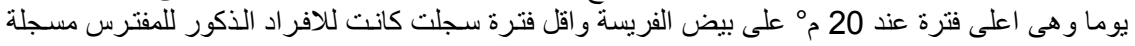

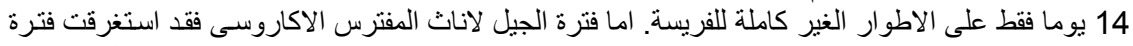

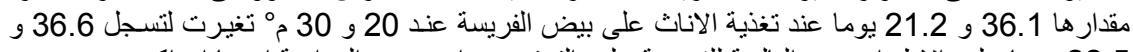

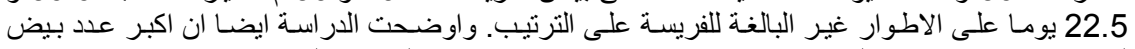

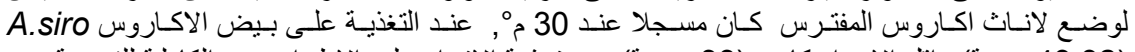

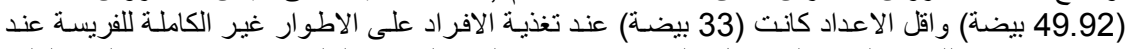

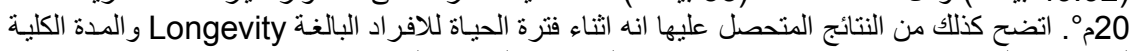

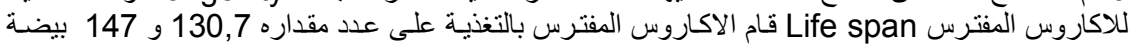

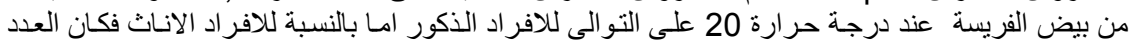

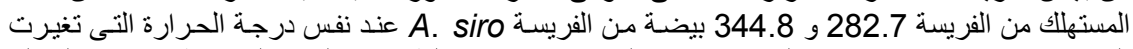

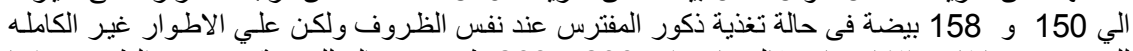

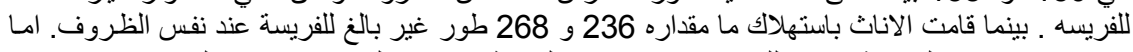

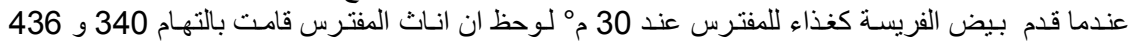

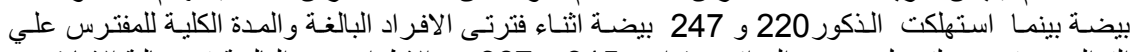

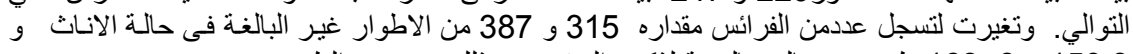

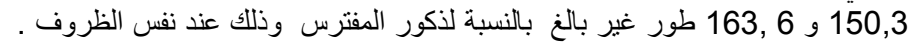

